\title{
PLANEJAMENTO MUNICIPAL PRECISA SER LEVADO A SÉRIO
}

Coluna publicada em 24.9.2013:<http://www.conjur.com.br/2013-set-24/ contas-vista-planejamento-municipal-levado-serio $>$

Na próxima segunda-feira (30/9), o prefeito do Município de São Paulo e os prefeitos da grande maioria dos Municípios do país apresentarão o projeto de Plano Plurianual (PPA) para o período de 2014-2017. A Constituição prevê o PPA no artigo 165 , I e $\$ 1^{\circ}$, devendo a apresentação do PPA federal ocorrer "até quatro meses antes do encerramento do primeiro exercício financeiro", conforme estabelecido "provisoriamente" no Ato das Disposiçõos Transitórias da Constituição, artigo 35, $\mathbb{2} 2^{\circ}, \mathrm{I}$, mas admite-se que essa norma tem natureza federal, aceitando-se que os demais entes da federação fixem datas próprias, ${ }^{1}$ como é o caso do Município de São Paulo, que estabelece o dia 30 de setembro, nos termos do artigo 138, $\$ 6^{\circ}$, II, da sua Lei Orgânica, o que também ocorre com a maioria dos demais municípios. É um momento muito relevante para a administração pública municipal, pois, como já expus em coluna anterior (No primeiro ano de mandato, não se cumprem promessas, nesta edição, p. 161-164), é nele que deverá estar materializado o plano de governo, explicitando-se as políticas públicas, programas e ações governamentais a serem implantados, continuados, incentivados e desenvolvidos ao longo dos próximos quatro anos. $\mathrm{Ou}$, de outro lado, também os que serão encerrados, descontinuados e desincentivados. É lá

1 Uma diferença de prazos que se justifica em face de nosso federalismo cooperativo, em que muitas das receitas dos entes subnacionais, especialmente dos municípios, provêm de transferências intergovernamentais oriundas da União e do Estado, sendo prudente conhecer antes a proposta orçamentária dos referidos entes federados e as perspectivas de concretização das transferências, conferindo maior credibilidade às previsões de receitas transferidas às leis orçamentárias municipais. E, no caso do PPA, releva também conhecer as previsões federais e estaduais de dados econômicos e sociais, tais como inflação, PIB, câmbio etc. que influenciarão nas previsões de arrecadação das receitas municipais. 
que se verificarão se as promessas de campanha efetivamente estão contempladas e, portanto, aumentando a expectativa de que venham a ser cumpridas e onde se espera encontrar a previsão de quais serão os investimentos públicos e políticas econômicas e sociais.

Trata-se de documento de fundamental importância não só para a administração pública, mas também para toda a sociedade, para os demais entes federados, o setor privado, o terceiro setor, enfim, a todos e a cada um de nós. Todos os cidadãos dependem, de alguma forma, em algum momento, das informaçôes sobre o que os municípios pretendem fazer nos próximos anos, para que possam tomar suas próprias decisóes.

Infelizmente, observa-se que não se tem dado a devida atenção ao tema e esse importante momento pode eventualmente até passar despercebido do público e não merecer a atenção da mídia. Até porque a apresentação da proposta de plano plurianual coincidirá com a apresentação da própria proposta de lei orçamentária anual do município para o ano de 2014, não só de São Paulo, como da grande maioria dos municípios do país, e será simultânea à apresentação da proposta de lei orçamentária dos Estados. Com todos esses documentos surgindo no mesmo dia, e referindo-se as propostas de lei orçamentária anual a questóes voltadas ao curto prazo, não é de se estranhar que se sobreponham, em termos de interesse do público, às diretrizes de médio prazo contidas nos planos plurianuais.

O planejamento governamental no Brasil é constituído por um sistema complexo e tem no PPA seu principal instrumento jurídico, como já exposto em detalhes na coluna anterior à qual já me referi. Não é o único, uma vez que as demais leis orçamentárias, como a Lei de Diretrizes Orçamentárias (LDO) e a própria Lei Orçamentária Anual (LOA) compõem esse sistema que abrange também muitas outras leis importantes, especialmente aquelas destinados a setores específicos da ação governamental, como é o caso do Plano Nacional de Educação.

Embora não se possa conceber atualmente a gestão de administrações públicas complexas, como é o caso dos entes que compõem nossa federação - União, Estados, Distrito Federal e municípios -, e de órgãos e instituições públicas que os integram, como o Poder Judiciário, Ministério Público, Universidades Públicas e tantos outros, sem um sistema de planejamento governamental bem elaborado e executado, parece que esta cultura ainda não está plenamente consolidada entre nós.

Vê-se que técnicas de planejamento e orçamento que começaram a surgir há um século, voltadas a buscar maior eficiência na administração pública, com orçamentos elaborados por programas, contabilizando-se as despesas de forma a buscar resultados, medindo e avaliando desempenho, incorporaram-se à administração 
pública apenas formalmente. Definições de estratégias, materializando-as nos instrumentos de planejamento governamental, com o estabelecimento de objetivos e metas de curto, médio e, por vezes, até longo prazo, parecem ficar apenas no papel e na boa intenção daqueles que elaboram os documentos, pois, na prática, nem sempre são executados, nem fiscalizados com o devido rigor, mitigando a credibilidade que deveriam merecer.

Planos plurianuais municipais, especialmente de municípios menores, são elaborados com base em modelos que se repetem ano a ano, sem uma efetiva preocupação dos prefeitos de nele incorporarem as previsóes para o que se vai fazer no decorrer do mandato. Mudam-se os prefeitos, alternando-se o partido e a ideologia de quem governa, com o povo esperançoso de mudanças, mas da leitura do PPA pouco ou nada se consegue constatar, deixando transparecer que nada vai se alterar.

Nota-se descaso com a cooperação federativa no planejamento, como se pode verificar na área de educação, em que o próprio governo federal ainda não aprovou o Plano Nacional de Educação, já se tendo esgotado há anos a vigência do anterior, como mencionado em outra coluna (Nem só com royalties se melhora a qualidade da educação, nesta edição, p. 55-58). E muitos municípios, que deveriam elaborar os Planos Municipais de Educação, para completar o sistema de planejamento neste setor fundamental para o desenvolvimento econômico e social do país, permanecem inertes. Segundo dados recentes do IBGE, 259 municípios paulistas ainda não elaboraram os respectivos planos e, no Brasil, são 2.181 municípios. ${ }^{2}$ Outras áreas, como saúde, apresentam distorçóes da mesma natureza. E não esqueçamos que a população foi às ruas recentemente exigindo melhorias nesses setores.

Um bom planejamento, dotado de clareza e transparência, é imprescindível para uma gestão eficiente e uso proveitoso dos recursos públicos. Planejar é escolher prioridades, ainda que essas escolhas sejam difíceis e importem em deixar de lado muitas ações relevantes - afinal, é para isto que os governantes são eleitos, esse é seguramente o maior ônus que pesa sobre seus ombros. Mas esta clareza e transparência nem sempre interessam aos que estão no alto comando da administração pública, que hesitam em desagradar a quem quer que seja, preferindo a opção política de, ainda que aparentemente, atender a todos, sem deixar claras as prioridades, até para não tornar transparente o que e quem não foi contemplado.

Daí porque, muitas vezes, nos deparamos com planos plurianuais genéricos, excessivamente abrangentes, incluindo praticamente tudo e para todos, deixando para a fase de execução, de forma opaca, a efetiva escolha do que vai ou não ser

$2<$ http://www.ibge.gov.br/home/estatistica/economia/perfilmunic/>. 
feito, tornando inúteis os instrumentos de planejamento para os fins a que se destinam. Muitas vezes, elaborados sem estudos e análises prévias sobre a realidade do município e seus problemas, transformam-se em documentos que não apontam as soluções adequadas e os meios para resolvê-los. Mais do que isso, deixam a critério do governante decidir ao sabor dos acontecimentos, tomando decisōes aleatoriamente para resolver problemas imediatos, de forma descoordenada e sem critérios, o que só tende a agravar as distorções da administração pública no médio e longo prazo.

Governar um município sem um plano plurianual sério, bem elaborado, precedido de estudos de cenários internos e externos, com escolhas criteriosas e democráticas de prioridades, fixando estratégias claras e bem definidas é como comandar um transatlântico no meio do oceano sem mapa, instrumentos de navegação e, principalmente, sem saber o porto de destino. Pouco importa cuidar da adequada limpeza, funcionamento da cozinha, da casa de máquinas e de tudo o mais que é necessário se o navio está verdadeiramente à deriva, pois o comandante sequer sabe para onde vai. "Navegar é preciso", já diziam os navegadores antigos, na frase imortalizada por Fernando Pessoa em seu poema. Mas é fundamental que se saiba a direção a seguir. Afinal - e aqui ousamos discordar do poeta e dos navegadores viver também é preciso. E viver bem, com dignidade, sem pobreza e desigualdades, como diz nossa Constituição.

“Deixa a vida me levar (vida leva eu!)”, diz a nossa música popular. É um belo refrão e é muito agradável ouvi-lo cantado por Zeca Pagodinho. Ajusta-se com perfeição às folgas de final de semana, alegra um dia de sol, com churrasco e cerveja, de bermuda e chinelos. Pode até ser um lema de vida. Mas não cai bem na caneta dos burocratas, com seus ternos e gravatas, durante a semana. Não é um lema a ser seguido pela administração pública. Esta precisa é de um bom planejamento, que se faz com seriedade, estudos criteriosos, programas bem construídos, resultados e metas ambiciosos, porém factíveis, para concretizar políticas públicas que vão conduzir aos objetivos fundamentais da sociedade e explicitados na Constituição.

Que nossos prefeitos não nos deixem à deriva. Vamos levar a vida na direção que nós queremos! 